\section{Indigenous oral health inequity: An Indigenous provider perspective}

Boozhoo, Wabishki Mitadim Ojichidaa Ikwe niin ndizhinikaaz. Hello, my name is White Horse Warrior Woman. I share this with you to help you understand its significance beyond what I am called. Although my spirit name was only revealed to an elder in ceremony a few years ago, I have always been White Horse Warrior Woman. Animate or inanimate, we all have a name, significance, roles, and ties here on Turtle Island. For me, this connects me to Mother Earth, my ancestors and to the land - a connection that Indigenous peoples in Canada have lost through colonization and the hushed atrocities committed against us.

From my spirit name comes the responsibility to protect those who need to be protected. I walk Mother Earth in many roles, guided by teachings and experiences shared by those I have encountered on my life journey. I am an Ojibway-Cree status First Nations mother, wife, sister, aunt, cousin, daughter, dentist, MPH graduate, and enrolled pediatric dentistry resident, to name a few. In these capacities, my responsibility to protect those who need to be protected lies in sharing in a humble way what I have learned about not only providing culturally safe dental care, but also changing harmful attitudes impacting the health of Indigenous Canadians.

For over a decade, I provided dental services in Indigenous communities. I initially came in hoping that I would eliminate or at least reduce the dental disease burden. I am sure we were each at one time optimistic about changing the world in a good way. About halfway into my dental career, I came to the realization that I was literally so busy dealing with the current dental disease, I had no opportunity to make that difference I wanted to make in future dental experience in my communities. Dental disease turned out to be more complicated than I anticipated it to be. Or was it?

Frustrated and feeling somewhat defeated, the time had come where I had to decide if I was going to continue with the status quo and policy of pushing patients through the clinic to satisfy program goals of productivity based on doing as many fillings or extractions as I could in a day, or suffer the consequences. To me, this approach to treatment is not complete. We send children and adult patients off for dental surgery to fix current dental disease and then send them right back into the environment that created the dental disease requiring surgery in the first place. Although we are treating our patients, we are only temporarily patching the problem. Unless we address the underlying factors, or the social determinants of health, this situation will never improve. If we can change the environment, we can make positive change. But is this even possible? And if yes, how do we do it?

For the next few years, this desire to create change drove me to search for answers. Academia was my most intensively explored area, but I also reached into practical and personal experience. This journey consumed my time and took much effort and resources to learn from various institutions, organizations, and individuals about the diversity of Indigenous culture and Indigenous research. Over this time, I gained comprehension of concepts that validated what I had already known and experienced. For me though, it was

\section{Les inégalités en santé buccodentaire autochtone : perspective $d$ 'une dispensatrice autochtone de soins de santé}

Boozhoo, Wabishki Mitadim Ojichidaa Ikwe niin ndizhinikaaz. Bonjour, je m'appelle White Horse Warrior Woman ou « Jument blanche-Guerrière ». Si je partage ce renseignement avec vous, c'est pour vous aider à comprendre son importance, qui dépasse celle d'un simple nom. Mon nom spirituel n'a été révélé à un ancien qu'il y a quelques années, lors d'un rituel, mais j'ai toujours été Jument blanche-Guerrière. Que nous soyons animés ou inanimés, nous avons tous un nom, une importance, un rôle et des liens ici sur l'île de la tortue. Mon nom me relie à la Terre-Mère, à mes ancêtres et au territoire - un lien que les Autochtones du Canada ont perdu avec la colonisation et les atrocités commises envers nous et qui ont été étouffées.

De mon nom spirituel me vient la responsabilité de protéger ceux qui ont besoin de protection. Durant mon passage sur la TerreMère, je joue plusieurs rôles, guidée par les enseignements et les expériences partagés par les personnes que j'ai rencontrées sur mon chemin de vie. Je suis membre inscrite de la Première Nation ojibway-crie, mère, épouse, sœur, tante, cousine, fille, dentiste, diplômée d'un programme de maîtrise en santé publique et résidente inscrite en dentisterie pédiatrique, pour ne nommer que quelques-uns de mes rôles. En ces qualités, ma responsabilité de protéger ceux qui ont besoin de protection consiste à partager en toute humilité ce que j'ai appris, non seulement sur la prestation de soins dentaires culturellement sûrs, mais sur les façons de changer les attitudes préjudiciables qui ont un impact sur la santé des Canadiens autochtones.

Pendant plus de 10 ans, j'ai dispensé des soins dentaires en milieu autochtone. Au départ, j'espérais pouvoir éliminer, ou au moins alléger, le fardeau des affections dentaires. Je suis sûre que nous avons tous et toutes un jour cru possible de changer le monde pour le mieux. Environ à mi-parcours de ma carrière de dentiste, j'ai réalisé que j'étais littéralement si occupée à traiter les maladies buccodentaires du moment que je n'avais aucune possibilité de faire bouger les choses comme je l'aurais souhaité pour que les expériences dentaires dans ma communauté soient meilleures à l'avenir. Il fallait bien l'admettre : les maladies buccodentaires étaient plus compliquées que je ne le pensais. Mais le sont-elles vraiment?

Frustrée et un peu dépassée, j'ai senti que le temps était venu de décider si j'allais poursuivre dans la même voie, en appliquant la politique de faire passer les patients par la clinique pour répondre aux objectifs de productivité - réaliser le plus de plombages ou d'extractions possibles par jour ou en subir les conséquences. À mon sens, cette stratégie de traitement est incomplète. Nous envoyons nos patients, enfants et adultes, en chirurgie dentaire pour réparer la maladie buccodentaire du moment, puis nous les renvoyons directement dans l'environnement qui a créé la maladie à l'origine de l'intervention chirurgicale. Nous traitons nos patients, mais nous ne faisons que remettre la solution du problème à plus tard. Si nous n'abordons pas les facteurs sousjacents ou les déterminants sociaux de la santé, la situation ne va jamais s'améliorer. En changeant l'environnement, nous pouvons apporter des changements positifs. Mais est-ce même possible? Et si oui, comment procéder? 
necessary to confirm, define, and build on that knowledge due to the controversial nature and anticipated resistance. I heard once in passing that those who bring up hard issues are blamed for being troublemakers. The justification given is that there is no problem until it is said out loud for all to hear.

There was not just one experience, thought or epiphany that brought me to where I am today. It was years of inquiring and asking questions, and years of listening and learning that taught me that oral health cannot be considered in isolation if we are to be successful in making change in the future. In public health, we are aware of the social determinants of health and how this pertains to Indigenous Peoples' health. This is not just a phenomenon that occurs in Canadian society, however. What causes Indigenous health inequity? Acknowledging and saying out loud that colonialism impacts contemporary Indigenous health is not enough to address health inequity. There is one saying from an elder that always comes to me: If we are going to talk the talk, we also have to walk the walk.

To successfully achieve cultural safety, it is necessary to learn about ourselves and recognize the power imbalance created by colonial ideologies and inherent racism that we carry, and then make appropriate changes. There are various forms of racism that we may unintentionally practice. For me, I learned in dental school to treat everyone in the clinic equally. This cultural blindness is damaging for our patients because that approach defaults on treatment of the dominant culture. If we create an unsafe environment, our patients will be reluctant or may not return for needed treatment. It is damaging because we create a barrier for our patients with regard to accessing dental care. Furthermore, equal treatment falls deficient when addressing health inequity. An apt analogy for understanding this difference would be to picture three individuals - one tall, one average height, and one short - trying to see over a solid fence. When treating everyone equally, we provide each with a standard stool or box appropriate to the needs of the average individual for seeing over the fence. Unfortunately, this approach fails to consider the needs of those requiring specific treatment so that they too can enjoy the same outcome as the average person. With equitable treatment, we provide stools or boxes appropriately sized for the individuals so that everyone is boosted to the same height and everyone can see over the fence. The goal of equitable treatment is to ensure that everyone receives the same positive outcomes.

What I continue to struggle with is providing a culturally safe environment while still improving health literacy. For example, we are aware that dental caries are preventable through brushing, flossing, and consuming a healthy diet, but how can we expect these of Indigenous patients when there are so many factors Canada has created that prevent Indigenous peoples from accomplishing them?

So what does this mean to researchers, practitioners, policymakers, and citizens of Canada? To make positive change, we must participate in Reconciliation and reach that goal of providing culturally safe care. Reconciliation to me means not only apologizing to Indigenous Canadians for the atrocities of the past, it means owning that apology by learning, accepting, and engaging in societal change so that Indigenous peoples can begin their own healing journey. Our culture, families, land, and way of life were assaulted and stolen for the benefit of others. It is not an
Les années suivantes, ce désir d'opérer des changements m'a poussée à chercher des réponses. Le milieu universitaire est celui que j'ai exploré le plus intensément, mais j'ai aussi acquis de l'expérience pratique et personnelle. Ce chemin a été long, et j'ai dû déployer beaucoup d'efforts et de ressources pour apprendre dans plusieurs établissements et organismes et auprès de nombreuses personnes toute la diversité de la culture autochtone et de la recherche autochtone. Pendant cette période, j'ai approfondi ma compréhension de concepts qui validaient ce que je savais déjà, pour l'avoir vécu. Mais il m'était nécessaire de vérifier ces connaissances, de les définir et de les renforcer, compte tenu de leur nature controversée et de la résistance que je prévoyais. J'ai entendu dire une fois, en passant, que l'on reproche à ceux qui posent des questions difficiles d'être des fauteurs de trouble. La raison donnée est qu'un problème n'existe pas tant qu'il n'est pas exprimé haut et fort.

Ce n'est pas qu'une expérience, une réflexion ou une illumination unique qui m'ont conduite où je suis aujourd'hui. Plusieurs années de recherches et de questions, d'écoute et d'apprentissage m’ont enseigné que la santé buccodentaire ne peut pas être considérée isolément si l'on veut réussir à changer les choses. En santé publique, nous sommes conscients des déterminants sociaux de la santé et de leur pertinence pour la santé autochtone. C'est d'ailleurs un phénomène qui ne touche pas seulement la société canadienne. Quelles sont les causes des inégalités auxquelles font face les Autochtones en matière de santé? Il ne suffit pas de reconnaître et de dire à voix haute que le colonialisme a des répercussions actuelles sur la santé autochtone pour aborder les inégalités de santé. Le dicton d'un ancien me revient toujours à l'esprit : Nos mots ne suffisent pas, il faut passer à l'action.

Pour parvenir à la sécurisation culturelle, il est nécessaire d'en apprendre davantage sur nous-mêmes, de reconnaître le déséquilibre des pouvoirs créé par les idéologies coloniales et le racisme inhérent que nous portons en nous, puis d'apporter les changements qui s'imposent. Il y a diverses formes de racisme que nous pouvons pratiquer sans le vouloir. Dans mon cas, j'ai appris à l'école de médecine dentaire à traiter tous les clients de la clinique sur un pied d'égalité. Cette cécité culturelle est dommageable pour nos patients, car elle opte par défaut pour le traitement accordé à la culture dominante. Si nous créons un environnement insécurisant, nos patients ne reviendront pas pour obtenir les traitements nécessaires, ou ils le feront à reculons. C'est aussi une stratégie dommageable parce qu'elle entrave l'accès de nos patients aux soins dentaires. De plus, l'égalité de traitement ne permet pas d'aborder les inégalités de santé. Une bonne analogie pour saisir cette différence est d'imaginer trois personnes, une grande, une moyenne et une petite, qui essaient de voir par-dessus une clôture pleine. Quand on les traite sur un pied d'égalité, on leur donne à chacune un tabouret ou une caisse de dimensions standard convenant aux besoins de l'individu moyen. Malheureusement, cette méthode ne tient pas compte de ceux qui ont besoin d'un traitement particulier pour obtenir le même résultat que l'individu moyen. Avec un traitement équitable, on offre des tabourets ou des caisses aux dimensions adaptées pour que chaque personne soit soulevée à la même hauteur et puisse voir par-dessus la clôture. L'objectif d'un traitement équitable est de faire en sorte que chacun obtienne les mêmes résultats positifs.

J'ai encore du mal à percevoir comment nous pourrions offrir un environnement culturellement sûr tout en continuant d'améliorer la maîtrise de l'information en santé. Par exemple, nous savons que la carie dentaire est évitable par le brossage des dents, l'utilisation de la soie dentaire et la saine alimentation, mais comment 
unreasonable expectation to receive an apology for what this country has done, and it most certainly is not unreasonable to expect those residing in this country to acknowledge and respect that apology by doing something about it.

My journey brought me here today. Not only do we have to look beyond oral health to address oral health, we must accept that Indigenous health inequity results from the imposition of colonialist ideology and failure to recognize, accept, and atone for the true Canadian history. Looking at the complete picture, the cause of Indigenous health inequity in fact falls at the feet of Canada, especially those who perpetuate damaging behaviour. There is much work to be done and this starts by locating ourselves, exploring who we are, determining what damaging baggage we carry and how we can correct centuries of bad behaviour. It is our responsibility as educated members of society to fix the mistakes of the past because ultimately, Indigenous health not only affects Indigenous people, it impacts all of Canada.

Sheri McKinstry, BSc, BSc(Dent), DMD, MPH, Currently enrolled in the Graduate Pediatric Residency Program, University of Manitoba, Winnipeg, $M B$

doi: $10.17269 / \mathrm{CJPH} .108 .6243$ pouvons-nous nous attendre à ce que les patients autochtones adoptent ces comportements quand ils en sont empêchés par tant de facteurs que le Canada a créés?

Qu'est-ce que cela signifie donc pour les chercheurs, les praticiens, les responsables des politiques et les citoyens du Canada? Pour opérer des changements positifs, nous devons absolument participer à la réconciliation et atteindre l'objectif d'offrir des soins culturellement sûrs. À mes yeux, la réconciliation, ce n'est pas seulement présenter des excuses aux Canadiens autochtones pour les atrocités du passé, c'est aussi faire siennes ces excuses par l'apprentissage, en acceptant les changements sociétaux et en y participant pour que les Autochtones puissent entreprendre leur propre cheminement vers la guérison. Notre culture, nos familles, notre territoire et notre mode de vie ont été attaqués et volés pour le bénéfice d'autrui. Il n'est pas déraisonnable de nous attendre à recevoir des excuses pour ce que ce pays nous a fait, et il n'est certainement pas déraisonnable de nous attendre à ce que les habitants de ce pays reconnaissent et respectent ces excuses en y donnant suite.

Mon chemin m'a amenée ici aujourd'hui. Non seulement devons-nous regarder au-delà de la santé buccodentaire pour aborder la santé buccodentaire, mais nous devons admettre que les inégalités auxquelles font face les Autochtones en matière de santé résultent de l'imposition d'une idéologie colonialiste et du défaut de reconnaître la véritable histoire du Canada, de l'accepter, et de réparer les torts causés. Si l'on regarde le portrait global, on s'aperçoit que les inégalités de santé des Autochtones sont la faute du Canada, et en particulier des Canadiens qui perpétuent des comportements préjudiciables. Il y a beaucoup de travail à faire, et ce travail doit commencer en nous situant, en explorant qui nous sommes, en déterminant quel bagage destructeur nous transportons et comment nous pouvons corriger des siècles de mauvais comportements. C'est à nous, les membres instruits de la société, de réparer les erreurs du passé, car en bout de ligne, la santé autochtone ne touche pas que les Autochtones, elle touche le Canada entier.

Sheri McKinstry, B.Sc., B.Sc.(Dent), D.M.D., M.S.P., Actuellement inscrite au programme de résidence en pédiatrie de l'Université du Manitoba, Winnipeg (Manitoba)

doi: $10.17269 / \mathrm{CJPH} .108 .6243$ 